\title{
PENETAPAN KADAR PENGAWET NATRIUM BENZOAT \\ PADA SAMBAL KEMASAN SECARA SPEKTROFOTOMETRI UV-VIS
}

\author{
(DETERMINATION OF SODIUM BENZOATE CONTENT \\ IN PACKAGED CHILI SAUCE USING UV-VIS SPECTROPHOTOMETRY)
}

\author{
KADE AYU YASINTA DEWI ${ }^{1}$, DEWA AYU IKA PRAMITHA ${ }^{1 *}$, DEBBY JULIADI ${ }^{1}$ \\ ${ }^{1}$ Program Studi DIII Farmasi, Akademi Farmasi Saraswati Denpasar
}

\begin{abstract}
Abstrak: Telah dilakukan penelitian mengenai penatapan kadar pengawet natrium benzoat pada sambal kemasan. Penelitian ini bertujuan untuk mengetahui adanya kandungan natrium benzoat pada sambal kemasan dan kadar natrium benzoat yang terdapat dalam sambal kemasan. Jumlah sampel yang digunakan pada penelitian ini adalah 6 sampel sambal kemasan pada beberapa merk yang beredar di pasar swalayan daerah Denpasar Barat. Analisa kualitatif pada penelitian ini dilakukan dengan cara pemisahan menggunakan dietil eter dan membentuk endapan ferri benzoat. Pada penetapan kadar natrium benzoat dapat dilakukan menggunakan spektrofotometri UV-Vis. Hasil pada penelitian ini ditemukan 2 sampel yang positif mengandung pengawet natrium benzoat dengan kadar $157,767 \mathrm{mg} / \mathrm{kg}$ untuk sampel A dan $182,8 \mathrm{mg} / \mathrm{kg}$ untuk sampel B. Namun, kadar yang didapatkan pada sampel A dan B tidak melebihi batas kadar yang terdapat pada Peraturan Menteri Kesehatan (permenkes) No 722/Menkes/PER/IX/88 yaitu 1000 mg/kg.
\end{abstract}

Kata Kunci: natrium benzoat, sambal kemasan, spektrofotometri UV-Vis

Abstract: Determination of sodium benzoate content in packaged chili sauce has been carried out the research. This study aims to determine the content of sodium benzoate in the packaging chili sauce and the level of sodium benzoate contained in the packaging chili sauce. The number of samples used in this study were 6 samples of packaged chili sauce on several brands circulating in the supermarket in the West Denpasar area. Qualitative analysis in this study was carried out by separating using diethyl ether and forming ferry benzoate deposits. The determination of sodium benzoate content can be carried out using UV-Vis spectrophotometry. The results of this study found 2 positive samples containing sodium benzoate preservative with levels of $157.767 \mathrm{mg} / \mathrm{kg}$ for samples A and $182.8 \mathrm{mg} / \mathrm{kg}$ for sample B. However, the levels obtained in samples A and B did not exceed the levels contained in Regulation of the Minister of Health (Permenkes) No 722 / Menkes / PER / IX / 88 which is $1000 \mathrm{mg} / \mathrm{kg}$.

Keywords: sodium benzoate, spectrophotometry UV-Vis, packaging chili sauce

\section{PENDAHULUAN}

Pabrik - pabrik makanan di Indonesia saat ini mengalami perkembangan yang sangat pesat dan saling bersaing untuk memperoleh produk yang bermutu. Kualitas makanan atau minuman tidak lepas dari berbagai faktor seperti proses pembuatan, kemasan dan penyimpanan. Faktorfaktor ini menentukan layak atau tidaknya suatu makanan yang dapat dikonsumsi. Berbagai proses pengolahan makanan dari sumber bahan mentah hingga penyajian makanan, dapat terjadi kontaminasi atau pencemaran terhadap bahan makanan. Makanan maupun minuman biasanya ditempatkan pada suatu wadah yang dipakai untuk dapat memperpanjang umur dari suatu makanan. Berdasarkan hal tersebut, maka Penggunaan Bahan Tambahan Pangan (BTP) dalam makanan terutama makanan olahan merupakan hal yang tidak dapat dihindari lagi (Zuraidah, 2007). Menurut Peraturan
Menteri Kesehatan Republik Indonesia Nomor722/Menkes/Per/IX/1988 tanggal 22 September 1988 dan Peraturan Menteri Kesehatan Nomor 1168/Menkes/PER/X/1999 terdapat beberapa jenis bahan tambahan pangan yang dilarang penggunaannya. Beberapa bahan tambahan pangan diantaranya asam borat dan senyawanya, asam salisilat dan garamnya, dietilpilokarbonat, dulsin, kalium klorat, kloramfenikol, minyak nabati yang dibrominasi, nitrofurazon, dan formalin (Saparinto dan Hidayati, 2006). Berdasarkan data tersebut, pengawet merupakan salah satu bahan tambahan pangan yang harus diperhatikan.

Makanan yang tidak habis dikonsumsi jika dibiarkan, teksturnya akan berubah dan dapat bersifat racun yang diakibatkan oleh pertumbuhan mikroba-mikroba yang ada dalam bahan makanan ataupun dari dekomposisi kompenen-kompenen bahan makanan yang dapat menghasilkan senyawa

\footnotetext{
*email korespondensi: ika.pramitha20@gmail.com
} 
racun. Untuk mencegah perkembangan mikrobamikroba zat dalam bahan pangan, perlu ditambahkan bahan-bahan tertentu lain sebagai bahan pengawet ke dalam bahan pangan tersebut (Rorong, 1996).

Bahan pengawet umumnya digunakan untuk mengawetkan pangan yang mempunyai sifat mudah rusak. Bahan ini dapat memperlambat proses fermentasi, pengasaman, atau penguraian yang disebabkan oleh mikroba. Akan tetapi, tidak jarang produsen menggunakan bahan pengawet tersebut pada pangan yang relatif awet dengan tujuan untuk memperpanjang masa simpan atau memperbaiki tekstur (Cahyadi, 2008). Bahan pengawet yang sering digunakan di dunia industri bahan makanan dan minuman dalam jumlah tertentu yaitu natrium benzoat. Natrium benzoat sering digunakan untuk mengawetkan berbagai makanan dan minuman, seperti sari buah, minuman ringan, saus tomat, saus sambal, selai, jeli, manisan, kecap dan lain-lain (Cahyadi, 2009). Peraturan Menteri Kesehatan (permenkes) No 722/Menkes/PER/IX/88, dimana nilai maksimal dari Natrium Benzoat yang diperbolehkan adalah $1000 \mathrm{mg} / \mathrm{kg}$. Efek dari mengkonsumsi natrium benzoat melebihi batas maksimum dapat menyebabkan kejang-kejang, hiperaktif, serta penurunan berat badan yang pada akhirnya dapat menyebabkan kematian (Nurcahyani, 2005).

Produk makanan olahan lokal yang terdapat di Indonesia sudah sangat banyak diproduksi dan diperjualbelikan, salah satunya adalah sambal kemasan. Sambal merupakan makanan yang wajib ada disetiap sajian masakan Indonesia, sehingga banyak produsen membuat olahan sambal siap saji yang dikemas sedemikian rupa. Tidak banyak dari makanan dalam kemasan yang tidak memiliki bahan pengawet sebagai bahan tambahan pada suatu makanan dalam kemasan. Menurut penelitian yang telah dilakukan oleh Siaka (2009), penggunaan pengawet benzoat pada saus sambal masih ada yang melebihi ambang batas yang telah ditentukan oleh Menteri Kesehatan Republik Indonesia sehingga penelitian ini perlu dilakukan untuk mengidentifikasi dan menetapkan kadar penggunaan pengawet natrium benzoat dalam produksi lokal yang beredar .

Berdasarkan hal tersebut di atas, mengingat kurang kepedulian masyarakat terhadap kesehatan, masyarakat perlu diberikan pengetahuan mengenai bahaya yang diberikan oleh penggunaan natrium benzoat sebagai bahan pengawet dalam makanan. Oleh karena itu, pada penelitian ini dilakukan pengujian mengenai kandungan natrium benzoat dalam sambal kemasan. Pada penelitian ini menggunakan metode utama spektrofotometri UV-Vis. Untuk mengetahui kadar natrium benzoat dalam sambal kemasan.

\section{ALAT, BAHAN, DAN METODE}

Alat. Timbangan analitik, spektrofotometer UVVis Double Beam (Shimadzu/UV-1800), corongpisah $100 \mathrm{~mL}$, labu takar $10 \mathrm{~mL} ; 25 \mathrm{~mL} ; 100$ $\mathrm{mL}$, erlenmeyer $50 \mathrm{~mL}$ (Herma); $250 \mathrm{~mL} ; 300 \mathrm{~mL}$ (Pyrex), beaker glass $250 \mathrm{~mL}$ (Pyrex), batang pengaduk, gelas ukur $50 \mathrm{~mL} ; 100 \mathrm{~mL}($ Herma), pipet ukur $1 \mathrm{~mL}, 2 \mathrm{~mL}$, penangas air.

Bahan. Bahan-bahan yang digunakan dalam penelitian ini adalah sambal kemasan yang di ambil dari pasar swalayan daerah Denpasar Barat, Akuades, Natrium Benzoat, Dietil eter, Asam Klorida, Natrium Hidroksida, Amonium Hidroksida, Natrium Klorida dan Besi III Klorida, etanol p.a.

Metode.

Pengambilan dan penyiapan sampel

Sampel sambal kemasan diambil dari beberapa merk yang beredar di pasar swalayan daerah Denpasar Barat. Selanjutnya sampel dianalisis di Laboratorium Akademi Farmasi Saraswati Denpasar.

\section{Prosedur Kerja}

a. Analisa Kualitatif Kandungan Natrium Benzoat dalam Sambal Kemasan

Sampel ditimbang sebanyak 10 gram ditambahkan $300 \mathrm{~mL}$ akuades kemudian dihancurkan dengan waring blender selama 2 menit ditambahkan $\mathrm{NaOH} 10 \%$ hingga basa dibiarkan selama 2 jam kemudian disaring. Filtrat $50 \mathrm{~mL}$ dimasukkan kedalam corong pisah, ditambahkan $\mathrm{HCl} 1 \mathrm{M}$ hingga asam (uji dengan kertas lakmus), diekstraksi sebanyak 3 kali dengan masing-masing $15 \mathrm{~mL}$ eter, lapisan air yang diekstraksi kembali. Ekstrak eter dicuci sebanyak 3 kali masing-masing dengan $5 \mathrm{~mL}$ akuades. Ekstrak eter yang telah dicuci dimasukkan kedalam cawan porselin, diuapkan di atas penangas air. Residu yang diperoleh dilarutkan dalam akuades. Setelah itu, dipanaskan $80-85^{\circ} \mathrm{C}$ selama 10 menit. Larutan tersebut ditambahkan dengan beberapa tetes $\mathrm{NH}_{3}$ sampai larutan menjadi basa, larutan diuapkan untuk menghilangkan kelebihan $\mathrm{NH}_{3}$. Residu yang tersisa dilarutkan kembali dengan air panas. Setelah itu ditambahkan beberapa tetes $\mathrm{FeCl}_{3}$ $0,5 \%$. Terbentuknya endapan ferribenzoat yang 
berwarna salmon (kecoklatan) menunjukkan adanya asam benzoat (Apriyantono dkk., 1989 dalam Siaka, 2009).

\section{b. Analisa Kuantitatif Kandungan Natrium Benzoat}

Sebanyak $1 \mathrm{~g}$ sampel ditimbang dengan teliti dan dimasukkan ke dalam gelas kimia $100 \mathrm{~mL}$ kemudian ditambahkan larutan $\mathrm{NaCl}$ jenuh hingga $20 \mathrm{~mL}$, ditambahkan dengan $\mathrm{HCl}$ sampai bersifat asam (kertas lakmus biru menjadi merah) selanjutnya dihomogenkan sampai sempurna. Dimasukkan ke dalam corong pemisah, pertama diesktrak dengan $7,5 \mathrm{~mL}$ dietil eter terbentuk 2 lapisan yaitu lapisan atas atau lapisan eter dipisahkan ke dalam gelas erlenmeyer sedangkan ekstrak eter dimasukkan ke dalam corong pemisah dan dicuci dengan $5 \mathrm{~mL} \mathrm{HCl} \mathrm{0,1 \% ,} \mathrm{lapisan} \mathrm{bawah}$ dibuang dan lapisan atas dicuci lagi dengan $4 \mathrm{~mL}$ $\mathrm{HCl} 0,1 \%$ dan seterusnya pencucian dilakukan dengan $3 \mathrm{~mL} \mathrm{HCl}$ 0,1\%. Ekstrak eter dimasukkan ke dalam labu takar $50 \mathrm{ml}$ dan dipaskan sampai garis batas dengan etanol $70 \%$ dan dihomogenkan. Kemudian larutan di uapkan di lemari asam, residu yang didapat dilarutkan dengan etanol 96\%. Proses ini dilakukan pengulangan sebanyak dua kali. Larutan yang didapat dibaca absorbansinya dengan menggunakan spektrofotometer UV-Vis pada panjang gelombang maksimum, kemudian konsentrasi asam benzoat dalam sampel ditentukan berdasarkan kurva standar (Helrick, 1990).

\section{c. Larutan Induk Natrium Benzoat 1000 ppm}

Sebanyak $10 \mathrm{mg}$ natrium benzoat p.a ditimbang dengan teliti dan dimasukkan ke dalam labu takar $10 \mathrm{~mL}$ kemudian dilarutkan dengan etanol p.a dan dipaskan sampai tanda batas kemudian dihomogenkan.

\section{d. Penentuan panjang gelombang maksimum}

Larutan standar natrium benzoat $10 \mathrm{mg} / \mathrm{mL}$, dipipet 1,0 mL dimasukkan ke dalam labu ukur 10 $\mathrm{mL}$ kemudian ditambahkan etanol sampai tanda batas, sehingga diperoleh larutan dengan konsentrasi $10 \mu \mathrm{g} / \mathrm{mL}$. Selanjutnya larutan diukur absorbansnya dengan spektrofotometer UV-Vis pada panjang gelombang 200-400 nm. Sebagai hasil pengukuran, diperoleh panjang gelombang maksimum dari standar natrium benzoat.

\section{e. Pembuatan kurva kalibrasi}

Disiapkan 5 buah labu ukur $10 \mathrm{~mL}$ yang sudah diberi label. Ke dalam masing-masing labu ukur dimasukan $2 \mathrm{~mL} ; 4 \mathrm{~mL} ; 6 \mathrm{~mL} ; 8 \mathrm{~mL}$ dari larutan stok. Kemudian diencerkan dengan etanol hingga tanda batas untuk mendapatkan konsentrasi bervariasi larutan standar. Masing-masing larutan standar diukur absorbansnya pada panjang gelombang maksimum.

\section{f. Penetapan Kadar Natrium Benzoat pada Sambal Kemasan}

Kadar natrium benzoat yang didapat dapat dihitung dengan rumus sebagai berikut:

Keterangan:

$$
\text { Kadar }=\frac{C x V x f p}{W}
$$

$\mathrm{C}=$ Konsentrasi natrium benzoat yang terdeteksi dalam sampel yang diukur kedalam Spektrofotometri UV $(\mathrm{mg} / \mathrm{kg})$.

$\mathrm{V}=$ Volume total sampel (L).

$\mathrm{Fp}=$ Faktor Pengenceran.

$\mathrm{W}=$ Berat Sampel $(\mathrm{Kg})$.

\section{HASIL DAN PEMBAHASAN}

Penelitian ini dilakukan untuk mengetahui kadar natrium benzoat pada sambal kemasan yang di jual di swalayan, kota Denpasar bagian Selatan. Pada pengambilan sampel digunakan metode simple random sampling secara acak dari berbagai swalayan di kota Denpasar Selatan tempat ini dipilih karena banyaknya masyarakat datang untuk mencari kebutuhan sehari-harinya di swalayan tempat pengambilan sampel.

Tabel 1. Hasil analisis kualitatif Natrium Benzoat

\begin{tabular}{cccc}
\hline No & Bahan Pangan & Benzoat & Keterangan \\
\hline 1 & Sambal kemasan A & - & Tidak terdapat endapan berwarna salmon atau cincin kecoklatan \\
2 & Sambal kemasan B & + & Terdapat endapan berwarna salmon atau cincin kecoklatan \\
3 & Sambal kemasan C & + & Terdapat endapan berwarna salmon atau cincin kecoklatan \\
4 & Sambal kemasan D & - & Tidak terdapat endapan berwarna salmon atau cincin kecoklatan \\
5 & Sambal kemasan E & - & Tidak terdapat endapan berwarna salmon atau cincin kecoklatan \\
6 & Sambal kemasan F & - & Tidak terdapat endapan berwarna salmon atau cincin kecoklatan \\
\hline \multicolumn{5}{l}{ Keterangan + : Endapan berwarna merah kecoklatan menandakan keberadaan benzoat dalam sampel. }
\end{tabular}

Uji Kualitatif Natrium Benzoat pada Sambal

Kemasan. Pada pengujian kualitatif yang dilakukan sampel yang didapat diperlakukan sesuai dengan prosedur kerja yang telah digunakan dari 6 sampel yang di uji 2 diantaranya mengandung natrium benzoat. Pereaksi yang digunakan untuk 
uji positif benzoat yaitu larutan $\mathrm{FeCl}_{3} 0,5 \%$ yang dapat membentuk endapan berwarna kecoklatan bila bereaksi dengan benzoat. Endapan yang terbentuk adalah basa besi (III) benzoat, $\left[\left(\mathrm{C}_{6} \mathrm{H}_{5} \mathrm{OH}\right)_{3} \mathrm{Fe} . \mathrm{Fe}(\mathrm{OH})_{3}\right]$.

Menurut Maidah, 2015 reaksi yang terjadi sebagai berikut :

$3 \mathrm{C}_{6} \mathrm{H}_{5} \mathrm{COOH}+\mathrm{FeCl}_{3} \rightarrow \mathrm{Fe}\left(\mathrm{C}_{6} \mathrm{H}_{5} \mathrm{COO}\right)_{3} \downarrow+3 \mathrm{HCl}$

Hasil analisis kualitatif natrium benzoat pada sampel sambal kemasan dalam kemasan dapat dilihat pada gambar 1 dan 2. Hasil analisis menunjukkan bahwa kedua sampel tersebut positif mengandung natrium benzoat pada ketiga ulangan yang dilakukan. Hal ini sesuai dengan komposisi yang tertera pada label kemasan yang menyebutkan bahwa kedua sampel tersebut mengandung natrium benzoat.

Uji Kuantitatif Natrium Benzoat pada Sambal Kemasan. Analisis kuantitatif berkaitan dengan penetapan berapa banyak suatu zat yang terkandung dalam suatu sampel (Day dan Underwood, 2002). Dalam penelitian ini kurva standar diperoleh dengan cara membuat seri konsentrasi 2, 4, 6, 8 ppm dari larutan standar natrium benzoat $10 \mathrm{ppm}$ sehingga diperoleh hasil absorbansi versus konsentrasi pada panjang gelombang $223 \mathrm{~nm}$.

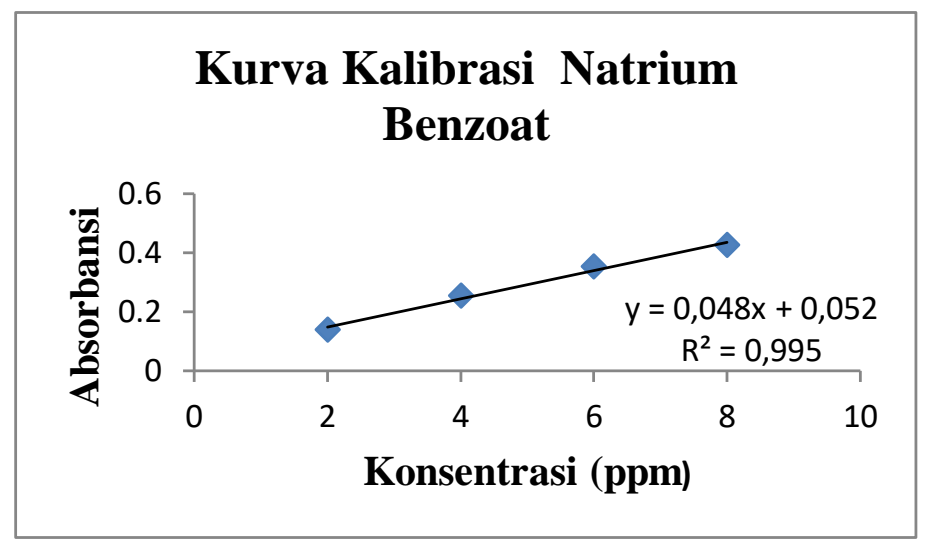

Gambar 1. Kurva kalibrasi standar natrium benzoat dalam etanol

Persamaan kurva kalibrasi merupakan hubungan antara sumbu $x$ dan sumbu y. Sumbu $x$ dinyatakan dengan konsentrasi yang diperoleh sedangkan sumbu y merupakan absorbansi atau serapan yang diperoleh dari hasil pengukuran sehingga persamaan regresi linier dari kurva kalibrasi yang diperoleh adalah $\mathrm{y}=0,048 \mathrm{x}-0,052$ dengan koefisien korelasi $\mathrm{r}=0,995$. Harga koefisien korelasi (r) yang mendekati 1 menyatakan hubungan yang linier antara konsentrasi dengan serapan yang dihasilkan, dengan kata lain peningkatan nilai absorbansi analit berbanding lurus dengan peningkatan konsentrasinya yang sesuai dengan kriteria penerimaan koefisien korelasi (r) yang baik (Shargel, 1985).
Penentuan kadar senyawa benzoat dalam sampel dilakukan dengan pengukuran absorbansi larutan sampel. Konsentrasi (X) senyawa benzoat dalam sampel diperoleh dengan cara mensubstitusikan nilai absorbansi larutan sampel terhadap (y) pada persamaan $\mathrm{y}=0,048 \mathrm{x}-0,052$. Penentuan konsentrasi yang terdapat dalam sampel sambal kemasan dapat dilihat dari jumlah konsentrasi rata-rata sampel yang merupakan jumlah konsentrasi senyawa benzoat yang terkandung dalam $10 \mathrm{mg}$ bahan saus sambal yang diperoleh berdasarkan pembacaan absorbansi dari $10 \mathrm{~mL}$ hasil ekstrak terakhir dalam rangkaian prosedur analisis kuantitatif.

Tabel 2. Tabel hasil pengukuran konsentrasi senyawa benzoat

\begin{tabular}{ccccc}
\hline No & Bahan Pangan & Absorbansi & $\begin{array}{c}\text { Kadar Natrium } \\
\text { Benzoat (ppm) }\end{array}$ & $\begin{array}{c}\text { Kadar natrium } \\
\text { Benzoat } \pm \text { SD }\end{array}$ \\
\hline \multirow{2}{*}{1} & Sampel kemasan A & 0.808 & 15,75 & \\
& & 0.811 & 15,81 & $157,7670 \pm 0,0019$ \\
& & 0.809 & 15,77 & \\
2 & \multirow{2}{*}{ Sampel kemasan B } & 0.922 & 18,12 & $182,80 \pm 0,826$ \\
& & 0.930 & 18,37 & \\
\hline
\end{tabular}


Penentuan konsentrasi yang terdapat dalam sampel sambal kemasan dapat dilihat dari jumlah konsentrasi rata-rata sampel yang merupakan jumlah konsentrasi senyawa benzoat yang terkandung dalam $10 \mathrm{mg}$ bahan saus sambal yang diperoleh berdasarkan pembacaan absorbansi dari $10 \mathrm{~mL}$ hasil ekstrak terakhir dalam rangkaian prosedur analisis kuantitatif.

Berdasarkan Tabel 2 konsentrasi senyawa benzoat dalam sampel sambal kemasan A dan B yaitu 157,767 dan $182,8 \mathrm{mg} / \mathrm{kg}$ menunjukkan kadar senyawa benzoat tidak melebihi ambang batas menurut Peraturan Menteri Kesehatan (permenkes) No 722/Menkes/PER/IX/88, nilai maksimal dari Natrium Benzoat yang diperbolehkan adalah $1000 \mathrm{mg} / \mathrm{kg}$. Penelitian ini dapat memberikan informasi kepada masyarakat bahwa sambal kemasan A dan B tidak membahayakan kesehatan masyarakat dan aman untuk dikonsumsi.

\section{KESIMPULAN}

Berdasarkan hasil penelitian tentang penetapan kadar pengawet pada sambal kemasan dengan spektrofotometri $U V$-VIS. Penggunaan pengawet natrium benzoat pada sambal kemasan dari 6 sampel yang diuji 2 diantaranya positif mengandung pengawet natrium benzoate dan kadar natrium benzoat yang didapat pada sampel A $157,767 \mathrm{mg} / \mathrm{kg}$ dan sampel B $182,8 \mathrm{mg} / \mathrm{kg}$ merupakan masih aman dari batas penggunaan pengawet natrium benzoat pada Peraturan Menteri Kesehatan No722/Menkes/PER/IX/88.

\section{UCAPAN TERIMAKASIH}

Ucapan terimakasih kepada laboratorium Akademi Farmasi Saraswati Denpasar dan Kepala Laboratorium Analisis Pangan Universitas Udayana serta seluruh pihak yang sudah membantu penelitian ini sehingga berjalan dengan baik dan lancar.

\section{DAFTAR PUSTAKA}

Badan Standarisasi Nasional. 1992. SNI 01-29731992. Syarat Mutu dan Cara Uji Biskuit. Jakarta.
Cahyadi, W., 2008. Analisis Dan Aspek Kesehatan Bahan Tambahan Pangan. Jakarta : Bumi Aksara.

Cahyadi. W., 2009. Analisis \& Aspek Kesehatan Bahan Tambahan Pangan. Edisi Kedua. Jakarta: Bumi Aksara.

Depkes, RI., 1988. Peraturan Menteri Kesehatan Republik Indonesia Nomor 722/MENKES/Per/IX/1988 tentang Bahan Tambahan Makanan. Jakarta.

Gandjar, I. G., 2007. Kimia Farmasi Analisis. Yogyakarta: Pustaka Pelajar.

Maidah. 2015. Analisis kualitatif dan kuantitatif natrium benzoat, boraks dan formalin dalam berbagai makanan olahan yang terdapat di lingkungan sekolah dasar kecamatan tamalanrea kota makassar. Skripsi. Jurusan Kimia Fakultas Matematika dan Ilmu Pengetahuan Alamuniversitas Hasanuddin Makassar. $<$ https://core.ac.uk/download/pdf/77623

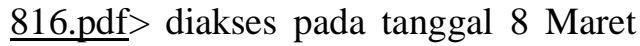
2018.

Nurcahyani. 2005. Analisis Kadar Natrium Benzoat dan Jenis Zat Aditif Pewarna Pada Saus tidak Bermerk di Pasar Dinoyo Malang. Skripsi Sarjana pada FMIPA Universitas Muhammadiyah Malang. $<$ http://digilib.umm.ac.id/go.php?id=jipt ummpp-gdl-s1-2005-nurcahyani-3390> diakses pada tanggal 8 Maret 2018.

Rorong, J.A., 1996. Analisis Asam Benzoat dan Sorbat Sebagai Bahan Pengawet Pada Berbagai Bahan Pangan Secara Spektrofotometri UV-Vis, Tesis, Program Pascasarjana MIPA- Kimia. Univeresitas Gadjah Mada Yogyakarta.

Saparinto, C dan Hidayati, D., 2006. Bahan tambahan Pangan. Yogyakarta: Kanisius.

Shargel, L. 1985. Biofarmasetika dan farmakokinetika Terapan. Penerjemah Fasich. Edisi kedua

Siaka. 2009. Analisis Bahan Pengawet Benzoat Pada Saos Tomat yangBeredar di Wilayah Kota Denpasar. Jurnal Kimia 3 (2): 87-92. 
SNI (Standar Nasional Indonesia), Cara Uji Bahan pengawet Makanan dan Bahan Tambahan yang di larang untuk makanan, Pusat Standarisasi Industri Departemen Perindustrian , 1-01-0222-1995.

Yuwano, M. and Indriyanto, G., 2005. Validation of chomatographic methods of analysis.
Profiles of drug substances excipients and related methodology, Vol. 32 : 243-259

Zuraidah, Y., 2007. Faktor-Faktor yang Berhubungan dengan Penggunaan Formalin pada Pedagang Tahu di Pasar Flamboyan Kota Pontianak. Ilmiah Pannamed 2(1): 9-12. 